\title{
Implementing Collective Impact for food systems change: Reflections and adaptations from Michigan
}

\author{
Lesli Hoey ${ }^{\text {a* }}$ \\ University of Michigan \\ Kathryn Colasanti ${ }^{\mathrm{b}}$ and Rich Pirog ${ }^{\mathrm{c}}$ \\ Michigan State University \\ Lilly Fink Shapiro ${ }^{d}$ \\ University of Michigan
}

Submitted November 30, 2016 / Revised March 16, 2017 / Accepted March 20, 2017 /

Published online March 29, 2017

Citation: Hoey, L., Colasanti, K., Pirog, R., \& Fink Shapiro, L. (2017). Implementing Collective Impact for food systems change: Reflections and adaptations from Michigan. Journal of Agriculture, Food Systems, and Community Development, 7(2), 101-115. http://dx.doi.org/10.5304/jafscd.2017.072.014

Copyright (C) 2017 by New Leaf Associates, Inc.

\begin{abstract}
As Collective Impact (CI) gains popularity across food systems change efforts, few scholars and practitioners have evaluated whether this collaborative social-change framework is well suited to food systems work. We begin to answer this question based on our own experience applying a CI model to support statewide goals established in the Michigan Good Food Charter. Our reflections are based on the project's evaluation findings, internal staff discussions about their CI-based efforts,

a * Corresponding author: Lesli Hoey, Assistant Professor, Urban and Regional Planning Program, University of Michigan; 2000 Bonisteel Blvd., Art and Architecture Building; Ann Arbor, Michigan 48109; 1hoey@,umich.edu

b Kathryn Colasanti, Michigan Good Food Coordinator, Michigan State University, Center for Regional Food Systems, Michigan State University; 480 Wilson Road, Natural Resources Building; East Lansing, Michigan 48824; colokat@msu.edu
\end{abstract}

discussions with other food systems practitioners using CI, and a review of emerging literature where scholars and practitioners evaluate or reflect on facilitating a CI initiative. The Michigan experience largely corroborates what is emerging in the broader criticisms of CI: that limited guidance exists about how to implement various elements of the model, that $\mathrm{CI}$ is relatively silent on policy

\footnotetext{
c Rich Pirog, Director, Michigan State University, Center for Regional Food Systems, Michigan State University; 480 Wilson Road, Natural Resources Building; East Lansing, Michigan 48824; rspirog@msu.edu

d Lilly Fink Shapiro, Program Manager, Sustainable Food Systems Initiative; 3531 Dana School of Natural Resources and Environment, University of Michigan; 440 Church Street, Ann Arbor, Michigan 48109-1041; finkshap@,umich.edu

Author note

Funding in support of this research was provided by the W. K. Kellogg Foundation.
} 
advocacy, and that, unless intentionally integrated, it has the potential to exacerbate, rather than address, inequities. However, our experience and that of other food systems practitioners also suggest that it is possible to transcend these limitations. We argue that groups expecting to make significant improvements to food systems can turn to $\mathrm{CI}$ as one of many social-change models that can guide their work, but only if lead organizations have the capacity to build trust and relationships between stakeholders and if they can thoughtfully integrate strategies for ensuring policy- and equity-based change.

\section{Keywords}

Collaboration; Collective Impact; Equity; Food Systems; Michigan; Networks; Policy

\section{Introduction}

Scholars and practitioners have long debated how to address "wicked" problems (Hamm, 2009; Rittel \& Webber, 1973; Xiang, 2013). The interconnected challenges affecting food systems are some of the most wicked, defined as problems that cross economic, social, health, and environmental realms, which require adaptive, multistakeholder solutions (Plastrik, Taylor, \& Cleveland, 2014; Weber \& Khademian, 2008). One strategy for addressing such systems-based challenges-Collective Impact (CI) - has been gaining popularity in nonprofit and foundation communities (Aspen Institute, 2013; Easterling, 2013; Kania \& Kramer, 2013; LeChasseur, 2016; Nee \& Jolin 2012; Weaver, 2014). The model has been adopted by initiatives addressing issues as diverse as juvenile justice reform, environmental protection, homelessness (Aragón \& Garcia, 2015; HanleyBrown, Kania, \& Kramer, 2012; Kania \& Kramer, 2013), and increasingly, food systems.

Emerging out of research on trends in philanthropy (Kramer, 2007, 2009), the CI concept was popularized by Kania and Kramer in 2011. The idea behind CI is to discourage problem-solving via single organizations, producing isolated outcomes, and instead to encourage collaboration across sectors and institutions to achieve collective, systemic impact. Kania, Kramer, and others suggest that CI initiatives require several key preconditions (influ- ential champions, sufficient funding, and a sense of urgency for change [HanleyBrown et al., 2012]) and five conditions to guide collaboration: a common agenda, mutually reinforcing activities, continuous communication, shared measurement, and one or more backbone organization(s) to facilitate the other conditions (Kania \& Kramer, 2011).

As practitioners apply CI to issues like obesity, food access, and local food economies (Fink Shapiro, Hoey, Colasanti, \& Savas, 2015; Pirog \& Bregendahl, 2012; Sands, Bankert, Rataj, Maitin, \& Sostre, 2014; Vermont Farm to Plate, 2013), few have evaluated whether the model is well suited to food systems work. We begin to answer this question by reflecting on the use of a CI model in our own efforts to support statewide goals established in the Michigan Good Food Charter. ${ }^{1}$ Our essay combines the perspectives of two lead coordinators at Michigan State University's Center for Regional Food Systems (CRFS) who are supporting statewide networking activities centered on the Charter (Colasanti and Pirog) and two of the external evaluators of a CRFS anchor project (Hoey and Fink Shapiro). Our reflections are based on findings from formative and developmental evaluations of CRFS's work (Patton, 2010) and staff discussions about their CI-based efforts. To situate our experience, we also draw on literature where scholars and practitioners evaluate or reflect on facilitating a CI initiative. We analyzed the literature inductively, looking for themes across these reflections (Creswell, 2013). The lead author also presented this essay's initial ideas with and gathered feedback from food systems scholars and practitioners with $\mathrm{CI}$ experience during one national and two local conferences.

In the remainder of this essay, we first explain how CRFS incorporates CI's five conditions into its work on the Michigan Good Food Charter. We then outline the emerging criticisms of CI from the literature and discuss ways CRFS and other practitioners have responded. The Michigan experience largely corroborates what is emerging in the

\footnotetext{
${ }^{1}$ See more detail about the MI Good Food Charter at http://www.michiganfood.org/. The charter's "vision and roadmap" calls for a "good food" system, that is, one that is "healthy, green, fair, and affordable" by 2020 .
} 
broader criticisms: that limited guidance exists about how to implement various elements of the model, that CI is relatively silent on policy advocacy, and that, unless intentionally integrated, it has the potential to exacerbate, rather than address, inequities. However, our experience and that of other food systems practitioners writing about their application of CI also suggest that it is possible to transcend these limitations. Doing so, we argue, requires lead organizations using a CI model to have the capacity to build trust and relationships between stakeholders and to thoughtfully integrate strategies for ensuring policy- and equity-based change.

\section{The CI Approach in Practice}

In Michigan, CRFS serves as one of the key backbone organizations behind achieving the Michigan Good Food Charter goals by facilitating the four other conditions of a CI approach. First, the six goals of the charter and 25 priority actions serve as the common agenda for a statewide food systems change initiative. The idea of the charter emerged in late 2009 when CRFS, along with the Food Bank Council of Michigan and the Michigan Food Policy Council, began discussing strategies for making Michigan's food system more equitable, sustainable and economically viable. Five work groups developed proposals and gathered feedback through a statewide summit and other means, eventually launching the Charter in June 2010. The Charter's goals focus on increasing local food purchasing that is profitable for local farmers and fair for their workers; building local agri-food business infrastructure; improving access to affordable, healthy food; and improving kindergarten-through-twelfthgrade (K-12) school meals and curricula.

Second, CRFS encourages mutually reinforcing activities by co-convening statewide networks focused on food councils, farm-to-institution initiatives, food hubs, the livestock sector, and a Michigan Good Food Charter Steering Committee. The intention is for these networks to enable diverse organizations to exchange information and partner with one another. CRFS also recently convened 15 to 20 additional food-related networks to discuss the potential of forming a Michigan network of networks to build the effectiveness of this collaborative work.

Third, CRFS manages regular communication channels for each of the networks it co-facilitates, including in-person and teleconferenced meetings, email lists, newsletters, social media, and webinars. Some of these networks (e.g., the Farm to Institution and Food Hub Networks) also meet jointly once a year, and all come together with the wider public and other networks every other year for the Michigan Good Food Summit.

Finally, CRFS co-coordinates a shared measurement project aligned with the Charter. This effort involves the development of data collection tools for organizations to compare common indicators across communities. Based on statewide stakeholder input, shared measurement activities currently focus on food access, institutional sourcing of local foods, and the economic impact of local food strategies.

\section{Criticisms and Emerging Adaptations}

As we noted at the outset, scholars and practitioners have raised three key criticisms about CI that should be of particular concern to food systems change agents using the approach. At the same time, CRFS and other practitioners' adaptations offer ways to address each weakness. These relate to strategies for operationalizing the model, addressing issues of equity, and influencing policy change.

\section{Limited Guidance Regarding Implementation}

First, many scholars and practitioners discuss the lack of evidence-based practices and specificity about how to implement CI's five conditions (Christens \& Inzeo, 2015; Flood, Minkler, Lavery, Estrada, \& Falbe, 2015; Wolff, 2016). This operational opaqueness makes it difficult to discern how appropriate the model is for food systems work. Despite their attempts to offer more implementation guidance (Hanleybrown et al., 2012), Kania, Kramer, and their colleagues routinely note that the CI framework is necessarily broad, so that it can be adapted to different contexts (Kania \& Kramer, 2011, 2013; Kania, Kramer, \& Russell, 2014). They describe how the approach requires an "ongoing progression of alignment, discovery, learning, and emergence... [and] continual unfold- 
ing of newly identified opportunities for greater impact, along with the setbacks that inevitably accompany any process of trial and error" (Kania \& Kramer, 2013, p. 2).

Paradoxically, rather than a complex, adaptive process, other scholars argue that the CI framework is sometimes presented as a recipe (Meter, 2014) or technocratic exercise (Connolly, 2011) that involves "the methodical structuring of relationships and activities to execute against [a preestablished] agenda" (Lanfer, Brandes, \& Reinelt, 2013, p. 73). Pirog (Personal communication, August 15, 2016) has seen this happen when a foundation imported the expertise from one successful CI initiative to unsuccessfully apply the same approach to a second project related to local healthy food access in a different state. He argues that this effort was destined to fail, not because the foundation used the CI framework, but because it did not engage local partners' agency and selfdetermination - a basic tenant of any participatory initiative (Arnstein, 1969; Forester \& Theckethil, 2009).

The oversimplified, recipe approach to CI has not been the case in Michigan. As Kania and Kramer suggest, CRFS has routinely responded to Michigan's unique and dynamic institutional, economic, and social context. While it has not fully addressed concerns about CI's need for further evidence-based implementation guidance, CRFS's experience (similarly to other CI users) offers lessons about when to implement the five conditions, ways to structure communication, how to approach shared measurement, and whether to emphasize relationship-building and shared goals over collective actions.

\section{When to implement the five conditions}

CI proponents maintain that initiatives may not attain positive outcomes if each of the five conditions of the model is not robust (HanleyBrown et al., 2012; Kania \& Kramer, 2011). This does not mean that each element of the model must be implemented together or in a particular order (Kania \& Kramer, 2013), but it does imply that project coordinators will have all of the conditions in mind during the initial planning process. We have found instead that many of these steps may emerge unplanned. Organizing for the Michigan Good Food Charter began in 2009, well before CRFS staff began referring to their work as "Collective Impact" in 2012. They adopted the model a year after Pirog was hired as associate director of CRFS, as a result of his familiarity with the approach and his experience using CI in a previous position in Iowa. While CRFS staff knew more generally about social network and other theories of social change, they felt the five CI conditions offered them the clearest framework to guide their ongoing collaborative work. Their decision to adopt the model was also legitimized when the W.K. Kellogg Foundation spoke at a grantee meeting about its interest in CI in 2011. Similarly, when the Leopold Center for Sustainable Agriculture adopted a CI model in Iowa, staff believed CI offered a useful framework to retroactively explain the complex networks and communities of practice Leopold Center coordinators were already facilitating across Iowa's growing local food sector (Pirog \& Bregendahl, 2012).

These experiences suggest that other food systems practitioners may also discover that $\mathrm{CI}$ helps explain their complicated change effort. Alternatively, even if actors do not believe they can implement the full CI approach, they may eventually build the capacity to adopt the entire model. Food policy councils, for instance, implement (often unknowingly) elements of a CI model but usually operate without a clear backbone organization or shared measurement until they can secure funding and dedicated staff (Center for a Livable Future, 2015).

\section{Ways to structure communication}

CRFS has also found that communication should be multifaceted, but may not need to be as "continuous" as CI texts suggest. Some of the original writings about $\mathrm{CI}$ described intensive, in-person communication. This was true of one program the CI model is based on that involved 15 education networks in the Cincinnati region. Each network met every two weeks for two years, which Kramer, Parkhurst, and Vaidyanathan (2009) believe contributed to "building trust and enabling learning that a shorter or less intensive process could not have achieved" (p. 20). In Michigan, however, such 
frequent, face-to-face interaction would be impossible, since traveling across the state can take more than seven hours. Other regional food systems initiatives have also noted that they try to avoid tiring participants with "death by meetings" (Fink Shapiro et al., 2015, p. 7).

Instead, CRFS relies on diverse forms of communication. Many of these are virtual, including one-way information flows (e.g., newsletters, websites, reports), but also interactive fora (e.g., email lists, webinars, conference calls). The Michigan Local Food Council Network, for instance, started hosting monthly calls that focus on topics members propose in advance (e.g., the Michigan House bill on urban agriculture), along with time to share experiences or ask questions. Coordinators have found that the open space, in particular, has encouraged cross-mentoring and immediate feedback about problems councils are facing. Most networks also host regional, in-person meetings three to four times a year. These meetings draw members of a network together-such as the Food Hub Network - and base activities on the chosen location (e.g., community-based tours, local speakers), while simultaneously encouraging an openness to innovations and new ideas through dedicated time for cross-state sharing and unstructured networking.

CRFS staff and other stakeholders are also starting to act as boundary spanners-people who can look for opportunities for cooperation across networks. This is similar to the Appalachian Foodshed Project's efforts to establish "double links" (a concept from the dynamic governance model), people who can participate in more than one committee or network (Fink Shapiro et al., 2015). These ideas build on social capital theories about "bonding" and "bridging." Where bonding connects individuals with similar backgrounds across multiple settings and roles, bridging connects diverse actors to each other and others from outside the community, expanding the diversity of stakeholders involved in solving complex problems (Agranoff \& McGuire, 2001; Flora \& Flora, 2003; Lasker \& Weiss, 2003). Other statewide and multistate food systems initiatives using a CI model also appear to be using a variety of virtual and in-person strategies to stay in touch
(Fink Shapiro et al., 2015). Taken together, this more eclectic communication approach is dynamic and multifaceted, allowing for overlapping strategies that offer multiple avenues for engaging in a CI endeavor.

\section{How to approach shared measurement}

CI proponents also insist that all stakeholders engage in shared measurement (HanleyBrown et al., 2012; Kania \& Kramer, 2013); however, the experience in Michigan has shown that the process of discussing measurement priorities can yield positive outcomes, even if some participating organizations never engage in shared data collection. One unforeseen challenge in Michigan has been the lack of capacity of community groups and nonprofits to participate in measurement activities, requiring a prior step to build data collection and analysis skills. Discussions about what to track and who will engage in data collection and analysis have also proven to be time intensive. On the other hand, CRFS staff have observed how discussions and trainings have exposed participants to new strategies for understanding the impact of their work and expanded relationships between organizations. For example, participants in a workshop on food system economic impacts had formed an average of 2.7 new partnerships with other organizations six months later (Hoey et al. 2016). Shared measurement discussions are also helping establish a norm of equitable data sharing; organizations are increasingly asking CRFS staff how they can best align with statewide efforts before engaging in their own data-collection efforts.

CRFS's experience is also reflected in evaluation expert Cabaj's (2014) observations, who argues that shared measurement may not always be appropriate. He has seen CI groups' progress stall for years because they could not agree on common indicators to track., while he has also observed initiatives that have had considerable impact over many years despite having no shared measurement system in place. He has also seen CI projects suppress innovation because they focus only on actions that are measureable (Cabaj, 2014), as other studies of CI-based food systems initiatives have found (Hoey, Fink Shapiro, Gerber, \& S. Savas, 2016). 
Whether to emphasize relationship-building and shared goals over collective actions

Similar to their experience with shared measurement, CRFS staff believe the processes involved in applying a CI model, especially relationshipbuilding and shared goal-setting, may be the most important aspect of the CI model. Extensive stakeholder engagement during the development of the Michigan Good Food Charter and through the networks has allowed diverse organizations to recognize their shared values and how their efforts fit into a broader vision, without requiring agreement upon specific actions each will take. This has allowed the partnerships to create a diverse array of place-based strategies and encouraged an iterative approach to framing the problems and solutions, avoiding the pitfall of universal solutions sometimes associated with CI (Arias \& Brady, 2015; McAfee, Blackwell, \& Bell, 2015; Wolff, 2016). For example, rather than impose a single model to increase local food purchasing, partnerships emerging $^{2}$ out of the Farm to Institution Network are each customized to the sizes, types, and number of farmers in a certain location, the local food processing capacity, and the motivation and ability of hospitals, universities, and school districts to change purchasing practices (Thompson, Colasanti, \& Matts, 2016).

"Extensive social interaction" (Pirog \& Bregendahl, 2012, p. 12), relationship-building, and trust have also been important to collaborative communities of practice in the Iowa food system, the Food Solutions New England initiative, and other regional food systems initiatives (Burke \& Spiller, 2015; Fink Shapiro et al., 2015; Northeast Sustainable Agriculture Working Group, n.d.). Holley (2012) has similarly found that "complex reciprocity"-where participants help others without expecting reciprocation because they believe in the value of the network-is the tipping point at which collaborations are able to be more effective. Collaboration scholars have also found that network effects deepen as relationships and trust solidify (Ansell \& Gash, 2008; Innes \& Booher, 2000; Liberato, Brimblecombe, Ritchie, Ferguson,

${ }^{2}$ See "Faces of the Network" for stories about example partnerships at http://www.cultivatemichigan.org/spotlight
\& Coveney, 2011; Nowell, 2009; Vandeventer \& Mandell, 2007). In more recent writings, Kania, Kramer, and Rusell (2014) have also observed that, "The health of relationships between organizations and individuals in the system is often the missing link in explaining why programs and interventions ultimately succeed or fail" (p. 31).

Other research suggests that attempts to reach agreement on actions can sometimes be the downfall of collaborations. In one study, debates over strategy in a CI-style malnutrition program in Latin America caused lasting fissures in the nutrition coalition, even though stakeholders agreed on the overall goal (Hoey \& Pelletier, 2011). One Food \& Fitness collaborative applying a CI model also found that participating organizations agreed on the goal—to reduce obesity—yet had conflicting visions about how to mobilize community engagement to achieve their goal, which slowed their progress (Sands et al., 2014). Meter's (2014) account of CI efforts in Minnesota additionally shows how food systems initiatives that involve businesses may require them to differentiate themselves to compete for customers, intentionally reducing synergy and "mutually reinforcing activities," despite other ways they can still collaboratively build their sector (in this case, food co-ops).

\section{Silence in Regard to Policy Advocacy}

A second major area where CI proponents have received criticism relates to a sense that the model stops at the programmatic level, while conspicuously avoiding the word "advocacy" or "policy." As others argue, this obfuscates the reason collaborations are often needed: the gradual downsizing of government since the 1980s and outsourcing of many public services to the private sector or nonprofits (Christens \& Inzeo, 2015). Hanleybrown, Kania, and Kramer (2012) admit that the rapid adoption of CI approaches is likely due to the 2008 economic recession, which has forced communities and nonprofits to do even more with less funding. However, they downplay the possibility or importance of policy change, noting that "the appeal of CI may also be due to a broad disillusionment in the ability of governments around the world to take the lead to solve society's problems, causing people to look more closely at alternative 
models of change" (HanleyBrown, Kania, \&

Kramer, 2012, p. 2).

A substantial amount of reform related to food systems in the U.S. and globally has been led by grassroots movements (e.g., Altieri \& Toledo 2011), consumer demands (e.g., Conner, Montro, Montri, \& Hamm, 2009), and private sector-led initiatives (e.g., Harris, Lott, Lakins, Bowden, \& Kimmons, 2012), but equally important changes have also been led by, or achieved through, government reforms. This includes shifts in the U.S. farm bill and other national food policy agendas, as well as food labeling laws, bans against food marketing aimed at children, soda taxes, increased wages for food sector workers, and more (Bittman, Pollan, Salvador, \& De Schutter, 2014; Popkin \& Hawkes, 2016). As such, food systems scholars and practitioners are calling for even greater policy change (Allen, FitzSimmons, Goodman, \& Warner, 2003; Clark, Sharp, \& Dugan, 2015; Guthman, 2008; Imhoff, 2007; Jayaraman, 2015; Pothukuchi, 2009), while some specifically point out the policy gap in CI-based work, arguing that "without changing policies and systems, transformation at scale cannot be achieved" (McAfee et al., 2015, p. 6). The larger concern is that collaborative models like CI that shy away from policy change may further absolve government of its responsibility for creating and maintaining many of the health, economic, and environmental conditions that have caused food systems problems, either through problematic policies or a lack of progressive policy (Alkon \& Mares, 2012).

In Michigan, the Good Food Charter was first developed with the goal of engaging state legislators in food systems issues. Yet, in CRFS's view, an attempt to appeal to a broad array of stakeholders and policymakers across party lines led to a pragmatic, market-led framing that focuses largely on the economic potential of local food, slowing policy advocacy work. Charter-inspired stakeholders, including CRFS, have had success in leveraging federal and state support for market-based initiatives, including a federal Healthy Food Financing Initiative award (Michigan Good Food Fund, n.d.) and state match funding for the 10 Cents a Meal Program, focused on local food purchasing in 16 school districts (Groundwork Center for Resilient
Communities, 2016). More extensive policy changes, however, have been less apparent as they have been, for instance, in the Iowa CI initiative. Unlike the Michigan Good Food Charter, the equivalent Iowa Food and Farm Plan emerged in 2010 after six years of intensive local food network-building led the Iowa legislature to pass an amendment mandating the development of "policy and funding recommendations for supporting and expanding local food systems" (Leopold Center for Sustainable Agriculture, 2011, p. 5).

The Michigan Good Food Charter's slower policy traction, therefore, is likely due to it having been written by nongovernmental actors who were attempting to get the attention of policymakers, while in Iowa, policymakers asked for a plan to prescribe policy. Focusing on policy advocacy as a strategy for achieving the Charter goals also creates a tension with CRFS's efforts to build a "big tent" to draw together many people with different perspectives about a common issue (Gustaveson, 2012). CRFS's staff strengths and skills also lie in research, education, and outreach, as opposed to political organizing, while being employees of a public university can also constrain direct policy action. That said, food councils are spreading across Michigan, and it is the intent of CRFS to build their capacity to inform policy change. Furthermore, the slow uptake of and gaps in food policy advocacy is not unique to Michigan; knowledge about how to mainstream food systems issues in policy agendas is generally lacking (Pelletier et al., 2012; Raja, Picard, Baek, \& Delgado, 2014).

\section{Potential Unintended Impact on Inequities}

The final, major criticism of the CI model is that advocates have largely failed to encourage an analysis of or strategies for addressing entrenched power and inequity, as community development and other social change models have long emphasized (Arias \& Brady, 2015; Christens \& Inzeo, 2015; Flood et al., 2015; LeChasseur, 2016; Williams \& Marxer, 2014; Wolff, 2016). Rather, CI solutions are often discussed as universal, population-level goals without recognizing that different parts of the community may need customized engagement strategies and interventions (Arias \& Brady, 2015; LeChasseur, 2016; McAfee et al., 2015; Wolff, 
2016). Kania and Kramer (2015) have begun to acknowledge that issues of equity are a blind spot in their earlier writing. They and other scholars (McAfee et al., 2015; Wolff, 2016) have suggested that a focus on equity requires CI practitioners to disaggregate data - by race, income, gender, etc.to ask how different parts of the community are affected by an issue, as well as ongoing analysis about what strategies are most effective for whom. Disaggregated analysis, however, does not go far enough.

If food systems change agents choose to use a CI model without recognizing that it lacks a robust equity lens, we argue that they could reinforce the existing class, race, and gender inequities associated with nutrition security and food access, wages and working conditions in food industries, land ownership, and more 3 (Giancatarino \& Noor 2014; Guel, Henderson, Pirog, Kelly, \& Wimberg, 2017; Horst, 2017; Jayaraman, 2015; Reynolds \& Cohen, 2016; White, 2011). Food justice scholars are increasingly advocating for decision-makers to confront historical traumas tied to current food system inequities (e.g., the displacement of native people from land, histories of segregation), to pursue progressive ameliorative actions (e.g., member-owned food stores, sanctuary restaurants, etc.), and to ensure more democratic representation and communicative food system planning (Horst 2017; Cadieux \& Slocum, 2015; Tareen, 2017).

$\mathrm{CI}$, as it is currently promoted and interpreted, does not adequately incorporate this type of equity lens, for several reasons. First, CI may demand too much of the backbone organization(s), which can begin to make decisions for other partners and unintentionally create a top-down initiative (Wolff, 2016). Second, as in any new trend in philanthropy, a focus on CI could shift funding toward large, well-coordinated entities that have the capacity to serve as backbone organizations and away from smaller, community-based nonprofits that might not be able to serve such a role. Third, because the

\footnotetext{
${ }^{3}$ Also see articles included in the Journal of Agriculture, Food Systems, and Community Development issue devoted to commentaries on race and ethnicity in food systems work at https://www.foodsystemsjournal.org/index.php/fsj/issue/ view $/ 21$
}

model focuses on coordinating "CEO-level crosssector leaders" (Hanleybrown et al., 2012), such as directors of nonprofits, government agencies, and private-sector companies, it implies that the power of change rests with organizations rather than individuals, especially marginalized groups most affected by an issue (LeChasseur, 2016; Wolff, 2016). Even if organizations involved with a CI initiative work closely with communities, this could reinforce existing hierarchies of power, as most public officials and executive leaders of formal organizations are still primarily white, male and middle-class (LeChasseur, 2016).

Finally, the CI model fails to address how to handle power relations and conflict that can arise in change efforts that involve diverse community members. Particularly in food systems work, corporate-led approaches to solving food systems problems clash regularly with the social justice and food sovereignty tenents of community-based groups (Agyeman \& McEntee, 2014; Anada, 2011; Giorda, 2012; Jaffee \& Howard, 2010), complicating efforts that attempt to bring multiple stakeholders together when power differences are so stark. Post-political and other participatory planning scholars show how more powerful actors can co-opt collaborative decision-making processes to protect and legitimize their own interests (Arnstein, 1969; Roy, 2015; Susskind \& Cruikshank, 2006).

This can occur when power inequities and conflicts are bracketed out of collaborations, either by overlooking marginalized groups or by avoiding conflictive topics in order to reach an agreement (Roy, 2015). Even intentional efforts to balance multiple perspectives, Kaza (2006) argues, can lead to a "tyranny of the median" (p. 255), when groups settle on a decision where all agree, rather than equitybased, progressive action.

McAfee et al. (2015) argue that CI backbone organizations ultimately must have a "point of view" (p. 8) if they care about fairness and inclusion, compared to some CI texts that suggest the need to be "neutral" (O’Brien, Littlefield, \& Goddard-Truitt, 2013, p. 26). Collaboration scholars suggest that $\mathrm{CI}$ can be successful if backbone organizations can create spaces where genuine, open dialogue occurs and if they allow for "radical criticism, dissensus and disagreement” (Roy, 2015, 
p. 67). Forester (2009) also describes how an "activist mediator" can structure more inclusive dialogue, debate, and negotiated action plans even under the most divisive circumstances by doing things like incorporating sufficient time for colearning (e.g., time for personal histories, unstructured social events, search conferences, study groups) and establishing "ground rules" that are culturally sensitive (p. 5).

CI scholars have also argued that backbone organizations must not allow themselves to become the lead, but need the skills and humility to develop "coalition leadership" with communities, in pursuit of democratic governance (Wolff, 2016). Lead organizations must also have credibility with communities most affected by inequity and staff reflecting those communities, which are lessons being echoed in food systems work more generally (Horst, 2017; Pirog, Koch, \& Guel, 2015; Tarng, 2015). Scholars additionally suggest that integrating grassroots organizing into CI efforts may require training and support to build the "collaborative capacity" of both the backbone organization and community residents. This can include guaranteeing that the benefits of participating outweigh the costs for all stakeholders, teaching skills in negotiation and conflict resolution, understanding stakeholders' beliefs and assumptions about the problem, and building a strong sense of personal efficacy to be a part of the collaborative effort (FosterFishman, Berkowitz, Lounsbury, Jacobson \& Allen, 2001; Kirk \& Shutte, 2004; Lasker \& Weiss, 2003; Liberato et al., 2011; Nowell, 2009).

Reflective of these strategies, Food Systems New England has actively integrated a focus on equity in its CI work through trainings on racial equity, the formation of a Racial Equity and Food Justice working group, and an ambassador program that attracts other organizations committed to equity goals (Burke \& Spiller, 2015). The Michigan Good Food Charter already incorporated equity as one of the core values before CRFS started to apply a CI model. CRFS has also integrated racial equity across all strands of its work in recent years, including its new strategic plan. Among other things, this has included support of a racial equity work group started by the Michigan Good Food Steering Committee, the formation of a racial equity committee within CRFS, two years of racial equity trainings for CRFS staff and partners, an examination of internal hiring practices, and regular updates of its annotated bibliography on structural racism in the U.S. food system (Guel et al., 2017). CRFS also actively engages community-based groups, uses collaborative approaches to manage networks, and has begun asking applicants for seed grants to incorporate plans for diversifying their membership. Finally, disaggregated data CRFS has begun collecting should determine if any demographic groups are underrepresented in Charter networks.

Despite the progress CRFS has made applying an equity lens, staff acknowledge that this is still a work in progress. They continue to struggle with increasing the diversity of their own staff; understanding their appropriate role in advancing racial equity in food systems, given the many highly respected and long-standing racial equity organizations both in Michigan and nationally; navigating how directly to focus on racial equity while maintaining their core identity as a food systems organization; mediating power differences that might exist in some food system networks; and determining whether to and how they can engage directly in grassroots organizing. Many of these questions are being debated by other food systems organizations as well (Horst, 2017; Pirog, Koch \& Guel, 2015; Tarng, 2015), including CI-specific food initiatives (Sands et al., 2014). (See Table 1 for a summary of CRFS's application and adaptation of CI. )

\section{Conclusion}

Despite CI's shortcomings, CRFS still promotes its use for addressing food systems problems, with caveats. Based on emerging criticism and our own experience, we argue that if $\mathrm{CI}$ is interpreted narrowly, it would likely work best (a) with stakeholders who have major economic or decision-making power (e.g., foundations, major nonprofits, the business elite), time to stay in frequent communication, and the capacity to collect shared measurement data, and (b) if the problem of focus is technical, does not disproportionately affect resourcepoor or historically marginalized communities, and can be largely solved outside of government. In most cases, however, the very nature of food 
Table 1. Summary of CRFS Application and Adaptation of Collective Impact (Cl)

\begin{tabular}{|c|c|c|}
\hline Cl Condition & Broad CRFS Application & CRFS Adaptation \\
\hline Backbone organization & $\begin{array}{l}\text { CRFS co-convenes Charter-focused } \\
\text { networks, facilitates communication } \\
\text { across networks, and leads shared } \\
\text { measurement activities. }\end{array}$ & $\begin{array}{l}\text { CRFS has integrated the four conditions below when } \\
\text { they were appropriate, without necessarily having } \\
\text { planned to incorporate } \mathrm{Cl} \text { or various components from } \\
\text { the beginning. }\end{array}$ \\
\hline Common agenda & $\begin{array}{l}\text { CRFS helped gather cross-state } \\
\text { stakeholder input to develop six goals } \\
\text { and } 25 \text { priority actions outlined in the } \\
\text { Michigan Good Food Charter. }\end{array}$ & $\begin{array}{l}\text { The Charter already included an equity lens that CRFS } \\
\text { has increasingly incorporated into its Cl-based Charter } \\
\text { work. CRFS is interested in adding more of a policy } \\
\text { focus, but given CRFS's convening role, staff may need } \\
\text { to build the capacity or rely on other partners to carry } \\
\text { out policy advocacy, such as local food policy councils. }\end{array}$ \\
\hline $\begin{array}{l}\text { Mutually reinforcing } \\
\text { activities }\end{array}$ & $\begin{array}{l}\text { CRFS co-convenes networks on food } \\
\text { councils, farm-to-institution, food hubs, } \\
\text { and the livestock sector to create } \\
\text { opportunities for mutually reinforcing } \\
\text { activities to develop. }\end{array}$ & $\begin{array}{l}\text { Rather than trying to define state- or network-wide } \\
\text { collective actions, CRFS focuses largely on relationship- } \\
\text { building, which encourages place-based partnerships } \\
\text { to emerge and "boundary spanners" who look for } \\
\text { cooperation opportunities across networks. }\end{array}$ \\
\hline $\begin{array}{l}\text { Continuous } \\
\text { communication }\end{array}$ & $\begin{array}{l}\text { CRFS facilitates regional in-person } \\
\text { meetings, teleconferencing, email lists, } \\
\text { social media, newsletters, and webinars. }\end{array}$ & $\begin{array}{l}\text { CRFS ensures communication is dynamic and } \\
\text { multifaceted, but not necessarily as frequent or in- } \\
\text { person as Cl often assumes is necessary. }\end{array}$ \\
\hline Shared measurement & $\begin{array}{l}\text { CRFS is developing tools to measure } \\
\text { food access, institutional sourcing of } \\
\text { local foods, and the economic impact of } \\
\text { local food strategies. }\end{array}$ & $\begin{array}{l}\text { Additional time has been necessary to develop Cl } \\
\text { partners' shared measurement capacity. Discussions of } \\
\text { measurement priorities, even if some participating } \\
\text { organizations never engage in shared data collection, } \\
\text { has still built partner capacity in other ways, increased } \\
\text { interest in equitable data sharing, and helped build } \\
\text { relationships. }\end{array}$ \\
\hline
\end{tabular}

systems problems will likely have equity and policy implications and will require the perspectives of many actors who do not have the time or resources to engage in a highly intensive problem-solving process as the ideal CI model presumes. Yet, as our experience and that of other CI practitioners show, the flexibility of the CI model allows users to adapt the approach to these types of situations, but only if lead organizations have the capacity to build trust and relationships between stakeholders and if they can thoughtfully integrate strategies to ensure policy- and equity-based change. Funders who are often behind the spread of CI use should require and build the capacity of CI users to incorporate these currently underemphasized adaptations of the model (LeChasseur, 2016).

As the nascent academic research ${ }^{4}$ on CI builds (Flood et al., 2015; LeChasseur, 2016), more

\footnotetext{
${ }^{4}$ Also see a recent grant awarded by the W.K. Kellogg Foundation in December 2016 for research on CI at https://www.wkkf.org/grants/grant/2017/01/collectiveimpact-fieldwide-research-study-p3036146
}

evidence is needed to determine whether the types of adaptations we discuss are necessary in most food systems initiatives, and more generally, when and where the CI model is best applied. Such evidence could ameliorate potential misuse of the model (Christens et al., 2015; Wolff, 2016). An evaluation guide available for $\mathrm{CI}$ practitioners (Preskill, Parkhurst, \& Juster, 2014) can help gather feedback on whether, how, and why a CI initiative is making progress and can document the complex change process an intervention undergoes.

Research is also needed to understand why CI has become so popular, whether CI is more effective than other collaboration models (e.g., deliberative planning, networked governance, rural wealth creation) (Flora \& Flora, 2003; Forester, 2009; Castelloe, Watson, \& Allen, 2011) and whether the five CI conditions, and variations for implementing them, are critical to making progress. In particular, critics cite that CI proponents fail to build upon decades of findings from research that could offer insights about how to approach coalition formation, multisector collaboration, agenda 
setting, participatory planning, conflict mediation, and other strategies inherent to carrying out CI (e.g., Christens \& Inzeo, 2015; Forester, 1997, 2009; Innes \& Booher, 2004; Kegler, Rigler, \& Honeycutt, 2010; Potapchuk, 1999; Susskind \& Cruikshank, 2006). Such questions are especially important for change processes like those that confront most food systems problems, where issues of power, policy change, and equity must be addressed to achieve more durable and large-scale change.

\section{Acknowledgements}

We would like to thank staff from the Center for Regional Food Systems and University of Michigan Good Food Charter Phase II evaluation team for their contribution to ongoing conversations about our use of Collective Impact (CI), including Liz Genzler, Noel Bielaczyc, Judith Berry, Colleen Matts, Nicholas McCann, Sue Ann Savas, Leah Gerber, Stephanie Williams, and Andrew Jones. The evaluation team's advisory group also helped us reflect on $\mathrm{CI}$ and theories of change, including Barbara Israel, Jennifer Blesh, Rebecca Jablonski, and John Seeley. Finally, thanks goes to the journal editor and blind reviewers for their useful suggestions.

\section{References}

Agranoff, R. \& McGuire, M. (2001). Big questions in public network management research. Journal of Public Administration Research and Theory, 11(3), 295326. https://doi.org/10.1093/oxfordjournals. jpart.a003504

Agyeman, J., \& McEntee, J. (2014). Moving the field of food justice forward through the lens of urban political ecology. Geography Compass, 8(3), 211-220. http://dx.doi.org/10.1111/gec3.12122

Alkon, A. H., \& Mares, T. M. (2012). Food sovereignty in US food movements: Radical visions and neoliberal constraints. Agriculture and Human Values, 29(3), 347-359. http://dx.doi.org/10.1007/s10460-012-9356-z

Allen, P., FitzSimmons, M., Goodman, M., \& Warner, K. (2003). Shifting plates in the agrifood landscape: The tectonics of alternative agrifood initiatives in California. Journal of Rural Studies, 19(1), 61-75. https://doi.org/10.1016/S0743-0167(02)00047-5
Altieri, M. A., \& Toledo, V. M. (2011). The agroecological revolution in Latin America: Rescuing nature, ensuring food sovereignty and empowering peasants. The Journal of Peasant Studies, 38(3), 587-612. http://dx.doi.org/10.1080/03066150.2011.582947

Anada, R. (2011, September 18). Will Allen's Growing Power gets a million from slaver Wal-Mart [Blog post]. Retrieved from https://foodfreedom.word press.com/2011/09/18/will-allen-walmartgreenwash/

Ansell, C., \& Gash, A. (2008). Collaborative governance in theory and practice. Journal of Public Administration Research and Theory, 18(4), 543-571. http://dx.doi.org/10.1093/jopart/mum032

Aragón, T. J., \& Garcia, B. A. (2015). Designing a learning health organization for collective impact. Journal of Public Health Management and Practice, 21(Suppl. 1), S24-S33. https://www.ncbi.nlm.nih.gov/pubmed/25423053

Arias, J. S., \& Brady, S. (2015, April 15). 3 steps for advancing equity through Collective Impact [Blog post]. Retrieved from the Collective Impact Forum website: https://collectiveimpactforum.org/ blogs/11421/3-steps-advancing-equity-throughcollective-impact

Arnstein, S. R. (1969). A ladder of citizen participation. Journal of the American Institute of Planners, 35(4), 216-224. http://dx.doi.org/10.1080/01944366908977225

Aspen Institute, The. (2013, June 28). Aspen Institute funds opportunity youth grants in 21 US communities [Press release]. Retrieved from https://aspencommunitysolutions.org/aspeninstitute-funds-opportunity-youth-grants-in-21-uscommunities-press-release/

Bittman, M., Pollan, M., Salvador, R., \& De Schutter, O. (2014, November 7). How a national food policy could save millions of American lives. $W$ ashington Post. Retrieved from https://www.washingtonpost.com

Burke, J. D., \& Spiller, K. A. (2015). Food Solutions New England: Racial equity, food justice, and food system transformation. Journal of Agriculture, Food Systems, and Community Development, 5(4), 165-171. http://dx.doi.org/10.5304/jafscd.2015.054.027 
Cabaj, M. (2014). Evaluating Collective Impact: Five simple rules. The Philanthropist, 26(1), 109-124. Retrieved from https://collectiveimpactforum.org/

Cadieux, K. V., \& Slocum, R. (2015). What does it mean to do food justice? Journal of Political Ecology, 22, 1-26. http://ipe.library.arizona.edu/

Castelloe, P., Watson, T., \& Allen, K. (2011). Rural networks for wealth creation: Impacts and lessons learned from US communities. Asheville, North Carolina: Rural Support Partners. Retrieved from http://www.ruralsupportpartners.com/networkdevelopment.php

Center for a Livable Future. (2015). Food policy councils in North America: 2015 trends [PowerPoint presentation]. Retrieved from http://www.foodpolicynetworks.org/food-policyresources $/$ ?resource $=834$

Christens, B. D., \& Inzeo, P. T. (2015). Widening the view: Situating Collective Impact among frameworks for community-led change. Community Development, 46(4), 420-435. http://dx.doi.org/10.1080/15575330.2015.1061680

Clark, J. K., Sharp, J. S., \& Dugan, K. L. (2015). The agrifood system policy agenda and research domain. Journal of Rural Studies, 42, 112-122. http://dx.doi.org/10.1016/j.jrurstud.2015.10.004

Conner, D. S., Montro, A. D., Montri, D. N., \& Hamm, M. W. (2009). Consumer demand for local produce at extended season farmers' markets: Guiding farmer marketing strategies. Renewable Agriculture and Food Systems, 24(4), 251-259. http://dx.doi.org/10.1017/S1742170509990044

Connolly, P. M. (2011). The best of the humanistic and technocratic: Why the most effective work in philanthropy requires a balance. The Foundation Review, 3(1), Article 11. http://dx.doi.org/10.4087/ FOUNDATIONREVIEW-D-10-00039

Creswell, J. W. (2013). Research design: Qualitative, quantitative, and mixed methods approaches (4 ${ }^{\text {th }} \mathrm{Ed}$.). Thousand Oaks, California: SAGE.

Easterling, D. (2013). Getting to Collective Impact: How funders can contribute over the life course of the work. The Foundation Review, 5(2), Article 7. http://dx.doi.org/10.9707/1944-5660.1157

Fink Shapiro, L., Hoey, L., Colasanti, K., \& Savas, S. A. (2015). You can't rush the process: Collective Impact models of food systems change. East Lansing: Michigan State University Center for Regional Food Systems.
Retrieved from http:/ / foodsystems.msu.edu/ resources/collective impact models of food systems change

Flood, J., Minkler, M., Lavery, S. H., Estrada, J., \& Falbe, J. (2015). The Collective Impact model and its potential for health promotion: Overview and case study of a healthy retail initiative in San Francisco. Health Education \& Behavior, 42(5), 654 668. https://doi.org/10.1177/1090198115577372

Flora, C. B., \& Flora J. L. (2003). Rural communities: Legacy and change (2 ${ }^{\text {nd }}$ Ed.). Boulder, Colorado: Westview.

Forester, J. (1997). Beyond dialogue to transformative learning: How deliberative rituals encourage political judgment in community planning processes. In D. Borri, A. Khakee, \& C. Lacirignola (Eds.), Evaluating Theory-Practice and Urban-Rural Interplay in Planning (pp. 81-103). Dordrecht, Netherlands: Springer-Science and Business Media. https://doi.org/10.1007/978-94-011-5462-8 7

Forester, J. (2009). Dealing with differences: Dramas of mediating public disputes. Oxford, UK: Oxford University.

Forester, J., \& Theckethil, R. K. (2009). Rethinking risk management policies: From "participation" to processes of dialogue, debate, and negotiation. In U. F. Paleo (Ed.), Building Safer Communities: Risk Governance, Spatial Planning and Responses to Natural Hazards (pp. 34-43). Amsterdam, Netherlands: IOS.

Foster-Fishman, P. G., Berkowitz, S. L., Lounsbury, D. W., Jacobson, S., \& Allen, N. A. (2001). Building collaborative capacity in community coalitions: A review and integrative framework. American Journal of Community Psychology, 29(2), 241-261. http://dx.doi.org/10.1023/A:1010378613583

Giancatarino, A., \& Noor, S. (2014). Building the case for racial equity in the food system. Retrieved from the Center for Social Inclusion website: https://www.centerforsocialinclusion.org/buildingthe-case-for-racial-equity-in-the-food-system/

Giorda, E. (2012). Farming in Motown: Competing narratives for urban development and urban agriculture in Detroit. In Viljoen, A. and J. Wiskerke (Eds). Sustainable food planning: Evolving theory and practice (pp. 271-282). Wageningen, Netherlands: Wageningen Academic Publishers. https://doi.org/10.3920/978-90-8686-187-3 23 
Groundwork Center for Resilient Communities. (2016). 10 cents a meal for school kids \& farms: State pilot project overview. Traverse City, Michigan: Author. Retrieved from http://www.groundworkcenter.org/projects/ farm-to-school/10-cents-a-meal.html

Guel, A., Henderson, J., Pirog, R., Kelly, R. \& Wimberg, T. (2017). An annotated bibliography on structural racism present in the U.S. food system (4 ${ }^{\text {th }} \mathrm{Ed}$.). East Lansing: Michigan State University Center for Regional Food Systems. Retrieved from http:// foodsystems. msu.edu/resources/structural racism in us food system

Gustaveson, L. (2012, November 14). Creating 'the big tent'-Collaboration key to ending homelessness [Blog post]. Retrieved from the Impatient Optimists website: http://www.impatientoptimists. org/Posts/2012/11/Creating-The-Big-Tent-Collaboration-Key-to-Ending-Homelessness

Guthman, J. (2008). Neoliberalism and the making of food politics in California. Geoforum, 39(3), 11711183. http://dx.doi.org/10.1016/j.geoforum.2006.09.002

Hamm, M. W. (2009). Principles for framing a healthy food system. Journal of Hunger and Environmental Nutrition, 4(3-4): 241-250. https://doi.org/10.1080/19320240903321219

Hanleybrown, F., Kania, J., \& Kramer, M. (2012, January 26). Channeling change: Making Collective Impact work. Stanford Social Innovation Review. https://ssir.org

Harris, D., Lott, M., Lakins, V., Bowden, B., \& J. Kimmons. (2012). Farm to institution: Creating access to healthy local and regional foods. Advances in Nutrition, 3, 343-349. http://dx.doi.org/10.3945/an.111.001677

Hoey, L., Fink Shapiro, L.. Gerber, L., \& Savas, S. (2016). MSU Center for Regional Food Systems, Michigan Good Food Charter II Project, Year III Evaluation Report. Ann Arbor: University of Michigan.

Hoey, L., \& Pelletier, D. L. (2011). Bolivia's multisectoral Zero Malnutrition Program: Insights on commitment, collaboration, and capacities. Food and Nutrition Bulletin, 32(2, Suppl. 2), S70-S81. http://dx.doi.org/10.1177/15648265110322S204

Holley, J. (2012). Network weaver handbook: A guide to transformational networks. Network Weaver Publishing. Available from http://www.networkweaver.com/

Horst, M. (2017). Food justice and municipal government in the USA. Planning Theory \& Practice,
18(1), 51-70.

http://dx.doi.org/10.1080/14649357.2016.1270351

Imhoff, D. (2007). Food fight: The citizen's guide to a food and farm bill. Healdsburg, California: Watershed.

Innes, J. E., \& Booher, D. E. (2000). Planning institutions in the network society: Theory for collaborative planning. In W. Salet \& A. Faludi (Eds.), Revival of strategic spatial planning (pp. 175-189). Amsterdam: Royal Netherlands Academy of Sciences.

Innes, J. E., \& Booher, D. E. (2004). Reframing public participation: Strategies for the 21st century. Planning Theory and Practice, 5(4), 419-436. http://dx.doi.org/10.1080/1464935042000293170

Jaffee, D., \& Howard, P. H. (2010). Corporate cooptation of organic and fair trade standards. Agriculture and Human Values, 27(4), 387399. http://dx.doi.org/10.1007/s10460-009-9231-8

Jayaraman, S. (2005). "ROCing" the industry: Organizing restaurant workers in New York. In S. Jayaraman \& I. Ness (Eds.). The New Urban Immigrant Workforce: Innovative Models for Labor Organizing (pp. 143-151). Armonk, New York: M. E. Sharpe.

Kania, J., \& Kramer, M. (2011, Winter). Collective Impact. Stanford Social Innovation Review, 36-41. https://ssir.org

Kania, J., \& Kramer, M. (2013, January 21). Embracing emergence: How Collective Impact addresses complexity. Stanford Social Innovation Review, 1-7. https://ssir.org

Kania, J., \& Kramer, M. (2015, October 6). The equity imperative in Collective Impact. Stanford Social Innovation Review. https://ssir.org

Kania, J., Kramer, M., \& Russell, P. (2014). Strategic philanthropy for a complex world. Stanford Social Innovation Review, Summer, 26-37. https://ssir.org

Kaza, N. (2006). Tyranny of the median and costly consent: A reflection on the justification for participatory urban planning processes. Planning Theory, 5(3), 255-270. http://dx.doi.org/10.1177/1473095206068630

Kegler, M. C., Rigler, J., \& Honeycutt, S. (2010). How does community context influence coalitions in the formation stage? A multiple case study based on the Community Coalition Action Theory. BMC (Biomedical Central) Public Health, 10(90), 1-11. http://dx.doi.org/10.1186/1471-2458-10-90 
Kirk, P., \& Shutte, A. M. (2004). Community leadership development. Community Development Journal, 39(3), 234-251. http://dx.doi.org/10.1093/cdj/bsh019

Kramer, M. R. (2007, August). Philanthropy, aid, and investment: Creating a common language. Presentation at the 2007 Brookings Blum Roundtable (Session VI: Global Impact: Philanthropy Changing Development). Retrieved from https://www.brook ings.edu/events/2007-brookings-blum-roundtabledevelopments-changing-face-new-players-oldchallenges-fresh-opportunities/5/

Kramer, M. R. (2009). Catalytic philanthropy. Stanford Social Innovation Review, Fall, 30-35. https://ssir.org

Kramer, M., Parkhurst, M., \& Vaidyanathan, L. (2009). Breakthroughs in shared measurement and social impact. Boston, Massachusetts: FSG Social Impact Advisors. Retrieved from http://www.fsg.org/ publications/breakthroughs-shared-measurement

Lanfer, S., Brandes, P., \& Reinelt, C. (2013). Only connect: How an investment in relationships among social change leaders is changing them, their organizations, and their city. The Foundation Review, 5(1), Article 7. http://dx.doi.org/10.4087/ foundationreview-D-12-00028.1

Lasker, R. D., \& Weiss, E. S. (2003). Broadening participation in community problem solving: a multidisciplinary model to support collaborative practice and research. Journal of Urban Health, 80(1), 14-47. http://dx.doi.org/10.1093/jurban/jtg014

LeChasseur, K. (2016). Re-examining power and privilege in Collective Impact. Community Development, 47(2), 225-240. http://dx.doi.org/10.1080/15575330.2016.1140664

Leopold Center for Sustainable Agriculture. (2011). Iowa Local Food \& Farm Plan. Ames, Iowa: Leopold Center for Sustainable Agriculture. Retrieved from http://lib.dr.iastate.edu/leopold pubspapers/76

Liberato, S. C., Brimblecombe, J., Ritchie, J. Ferguson, M., \& Coveney, J. (2011). Measuring capacity building in communities: A review of the literature. BMC (Bio Medical Central) Public Health, 11, Article 850. http://dx.doi.org/10.1186/1471-2458-11-850

McAfee, M., Blackwell, A. G., \& Bell, J. (2015). Equity: The soul of Collective Impact. Oakland, California: PolicyLink. Retrieved from http://www.policylink. org/find-resources/library/equity-soul-ofcollective-impact
Meter, K. (2014). Metrics from the field: Co-ops and Collective Impact. Journal of Agriculture, Food Systems, and Community Development, 4(3), 11-14. http://dx.doi.org/10.5304/jafscd.2014.043.014

Michigan Good Food Fund. (n.d.). Frequently asked questions. Retrieved April 15, 2017, from http://migoodfoodfund.org/about/faq/

Nee, E., \& Jolin, M. (2012). Q\&A roundtable on Collective Impact. Stanford Social Innovation Review, Fall, 25-29. https://ssir.org/

Northeast Sustainable Agriculture Working Group. (n.d.). A model network: Food Solutions New England [Blog post]. Retrieved from http://nesawg.org/news/model-network-foodsolutions-new-england

Nowell, B. (2009). Profiling capacity for coordination and systems change: The relative contribution of stakeholder relationships in interorganizational collaboratives. American Journal of Community Psychology, 44(3-4), 196-212. http://dx.doi.org/10.1007/s10464-009-9276-2

O’Brien, J. D., Littlefield, J. N., \& Goddard-Truitt, V. (2013). A matter of leadership: Connecting a grantmaker's investments in collaborative leadership development to community results. The Foundation Review, 5(1), Article 4. http://dx.doi.org/ 10.4087 / foundationreview-D-12-00022.1

Patton, M. Q. (2010). Developmental evaluation: Applying complexity concepts to enhance innovation and use. New York: Guilford.

Pelletier, D. L., Frongillo, E. A., Gervais, S., Hoey, L., Menon, P., Ngo, T., Stoltzfus, R. J., Shamsir Ahmed, A. M., \& Ahmed, T. (2012). Nutrition agenda setting, policy formulation and implementation: Lessons from the Mainstreaming Nutrition Initiative. Health Policy and Planning, 27(1), 19-31. http://dx.doi.org/10.1093/heapol/czr011

Pirog, R., \& Bregendahl, C. (2012). Creating change in the food system: The role of regional food networks in Iowa. East Lansing: Michigan State University Center for Regional Food Systems. Retrieved from http:// foodsystems.msu.edu/resources/creatingchange

Pirog, R., Koch, K., \& Guel, A. (2015). Race, ethnicity, and the promise of "Good Food" for Michigan: A three-voice commentary. Journal of Agriculture, Food Systems, and Community Development, 5(4), 83-86. http://dx.doi.org/10.5304/jafscd.2015.054.011 
Plastrik, P., Taylor, M., \& Cleveland, J. (2014). Connecting to change the world: Harnessing the power of networks for social impact. Washington, D.C.: Island Press.

Popkin, B. M., \& Hawkes, C. (2016). Sweetening of the global diet, particularly beverages: Patterns, trends, and policy responses. The Lancet Diabetes \& Endocrinology, 4(2), 174-186. http://dx.doi.org/10.1016/S2213-8587(15)00419-2

Potapchuk, W. R. (1999). Building an infrastructure of community collaboration. National Civic

Review, 88(3), 165-170. http://dx.doi.org/10.1002/ncr.88301

Pothukuchi, K. (2009). Community and regional food planning: Building institutional support in the United States. International Planning Studies, 14(4), 349-367. http://dx.doi.org/10.1080/13563471003642902

Preskill, H., Parkhurst, M., \& Juster, J. S. (2014). Guide to evaluating Collective Impact: Learning and evaluation in the Collective Impact context. Boston, Massachusetts: FSG.

Raja, S., Picard, D., Baek, S., \& Delgado, C. (2014). Rustbelt radicalism: A decade of food systems planning practice in Buffalo, New York (USA). Journal of Agriculture, Food Systems, and Community Development, 4(4), 173-189. http://dx.doi.org/10.5304/jafscd.2014.044.015

Reynolds, K., \& Cohen, N. (2016). Beyond the kale: Urban agriculture and social justice activism in New York City. Athens, Georgia: University of Georgia Press.

Rittel, H. W. J., \& Webber, M. M. (1973). Dilemmas in a general theory of planning. Policy Sciences, 4(2), 155169. http://dx.doi.org/10.1007/BF01405730

Roy, P. (2015). Collaborative planning-A neoliberal strategy? A study of the Atlanta BeltLine. Cities, 43, 59-68. https://doi.org/10.1016/j.cities.2014.11.010

Sands, C. H., Bankert, S. C., Rataj, S., Maitin, M., \& Sostre, J. (2014). "Call for Partnerships": An innovative strategy to establish grassroots partnerships to transform the food and fitness environments. Community Development, 45(3), 263278.

http://dx.doi.org/10.1080/15575330.2014.902856

Susskind, L. E., \& Cruikshank, J. L. (2006). Breaking Robert's Rules: The new way to run your meeting, build consensus, and get results. Oxford, UK: Oxford University.

Tareen, S. (2017, January 25). Restaurants: The next front for the immigration debate? Associated Press. Retrieved from http://bigstory.ap.org/article/ 14f3e37bf9fc45c4a8b79bca3cc6d2fe

Tarng, D. W. (2015). Privilege and allyship in nonprofit food justice organizations. Journal of Agriculture, Food Systems, and Community Development, 5(4), 173-177. http://dx.doi.org/10.5304/jafscd.2015.054.029

Thompson, M., Colasanti, K., \& Matts, C. (2016). Understanding how Michigan institutions define local food. Lansing, Michigan: Michigan State University Center for Regional Food Systems. Retrieved from http://foodsystems.msu.edu/resources/understand ing-how-michigan-institutions-define-local-food

Vandeventer, P., \& Mandell, M. P. (2007). Networks that work: A practitioner's guide to managing networked action. Los Angeles: Community Partners.

Vermont Farm to Plate. (2013). Strategic Plan Chapter 4.8. Leadership + Collective Impact. Retrieved from http://www.vtfarmtoplate.com/plan/ chapter/4-8-leadership-collective-impact

Weaver, L. (2014). The promise and peril of Collective Impact. The Philanthropist, 26(1), 11-19. http://thephilanthropist.ca/2014/07/the-promiseand-peril-of-collective-impact/

Weber, E. P., \& Khademian, A. M. (2008). Wicked problems, knowledge challenges, and collaborative capacity builders in network settings. Public Administration Review, 68(2), 334-349. http://dx.doi.org/10.1111/j.1540-6210.2007. 00866.x

White, M. M. (2011). D-Town Farm: African American resistance to food insecurity and the transformation of Detroit. Environmental Practice, 13(4), 406-417. https://doi.org/10.1017/S1466046611000408

Williams, J. \& Marxer, S. (2014, September 4). Bringing an equity lens to Collective Impact [Blog post]. Retrieved from https://www.collectiveimpact forum.org/blogs/34176/bringing-equity-lenscollective-impact

Wolff, T. (2016, May 4). Ten places where Collective Impact gets it wrong [Guest editorial]. Global Journal of Community Psychology Practice, 7(1), 1-11. http://www.gjcpp.org

Xiang, W.-N. (2013). Working with wicked problems in socio-ecological systems: Awareness, acceptance, and adaptation. Landscape and Urban Planning, 110, 1-4. http://dx.doi.org/10.1016/j.landurbplan. $\underline{2012.11 .006}$ 